\title{
ANALISIS TUGAS PEKERJA SOSIAL DALAM MEMBERDAYAKAN LANJUT USIA DI WISMA LANSIA HUSNUL KHATIMAH SEMARANG
}

\author{
${ }^{1}$ Liana Evitasari, ${ }^{2}$ Bagus Kisworo \\ ${ }^{1,2}$ Jurusan Pendidikan Luar Sekolah, FIP, Universitas Negeri Semarang \\ Gedung A2 Kampus Sekaran Gunungpati Telp. 8508019 Semarang 50229 \\ lianaevitasari.pls14@gmail.com
}

\begin{abstract}
Abstrak
Penelitian ini bertujuan mendeskripsikan dan menganalisis tugas pekerja sosial dalam memberdayakan lanjut usia serta faktor pendorong dan penghambat dalam pelaksanaan tugas pekerja sosial dalam memberdayakan lanjut usia di Wisma Lansia Husnul Khatimah Semarang. Metode penelitian ini menggunakan pendekatan penelitian deskriptif kualitatif. Data dikumpulkan melalui observasi, wawancara, dan dokumentasi. teknik keabsahan data menggunakan triangulasi sumber dan metode. Teknik analisis data menggunakan pengumpulan data, reduksi data, display data, penarikan kesimpulan dan verifikasi. Tugas pekerja sosial dalam memberdayakan lansia dapat disimpulkan dilaksanakan setiap harinya melalui kegiatan sehari-hari yang secara sadar atau tidak melatih lansia menjadi produktif, mandiri, sehat, serta memiliki nilai religius. Faktor pendukung pelaksanaan tugas pekerja sosial dalam memberdayakan lansia yaitu rasa tanggung jawab dari dalam diri pekerja sosial serta lingkungan kerja yang kondusif, sedangkan faktor penghambatnya yaitu kondisi fisik serta psikis lansia yang tidak stabil.
\end{abstract}

Kata Kunci: Tugas, Pekerja Sosial, Pemberdayaan, Lanjut Usia.

\begin{abstract}
This study aims to describe and analyze social workers assignment in empowering answers and driving and inhibiting factors in carrying out the duties of social workers in empowering the holding of a day at elderly houses Husnul Khatimah Semarang. This research method uses a descriptive qualitative research design. Data collection, interviews and documentation. data validity techniques using triangulation methods and methods. Data analysis techniques use complete data, data reduction, data display, conclusions and verification. The task of social workers in empowering the elderly can be continued to carry out every month of daily activities carried out or not to train the elderly to be productive, independent, healthy, and have religious value. Factors that support social responsibility are members of the responsibilities of social responsibility and a conducive work environment, while the inhibiting factors are the unstable physical and psychological conditions of the elderly.
\end{abstract}

Keywords: Assignment, Social Worker, Empowerment, Elderly.

\section{PENDAHULUAN}

Indonesia, sebagai bagian dari masyarakat dunia, akhir-akhir ini telah memasuki fase peningkatan demografis yang sangat signifikan. Tingkat kelahiran serta penduduk lanjut usia yang tinggi juga merupakan penyebab adanya permasalahan tersebut. Pada tahun 2020-2030 di Indonesia diperkirakan akan mengalami bonus demografi, yaitu ketika jumlah penduduk usia produktif (15-64 tahun) lebih banyak dibandingkan dengan penduduk usia non produktif. Tentu saja ini menjadikan keuntungan besar bagi Negara Kesatuan Republik Indonesia, namun hal itu hanya apabila kita dapat memanfaatkan kesempatan tersebut dengan benar dan cermat. Apabila bonus demografi tersebut tidak ditangani dengan benar maka hanya akan 
menimbulkan lebih banyak permasalahan sosial, seperti tingkat pengangguran serta angka kriminalitas yang tinggi.

Adanya populasi Penyandang Masalah Kesejahteraan Sosial (PMKS) yang masih menjadi beban sosial diberbagai Kabupaten/Kota, baik jumlah maupun kompleksitasnya. PMKS tersebut seringkali tidak dapat melaksanakan fungsi sosialnya secara memadai dan wajar sehingga mengganggu pemenuhan kebutuhan hidupnya, misalnya akibat dari kemiskinan, ketelantaran, kecacatan, keterbelakangan, keterasingan, keterbatasan, perubahan lingkungan, penduduk usia non produktif, serta beberapa masalah sosial yang berdampak signifikan di Indonesia (Muthia, Krisnani, dan Meilany, 2016: 344).

Data menunjukkan bahwa penduduk lanjut usia di Indonesia termasuk terbesar keempat setelah China, India, dan Jepang. Karena usia harapan hidup perempuan lebih panjang dibandungkan laki-laki, maka jumlah penduduk lansia perempuan lebih banyak dibandingkan laki-laki (11,29 juta jiwa berbanding 9,26 juta jiwa). Sedangkan Badan Kesehatan Dunia (WHO) menjelaskan bahwa penduduk lansia di Indonesia pada tahun 2020 mendatang sudah mencapai angka $11,34 \%$ atau tercatat 28,8 juta orang, balitanya tinggal $6,9 \%$ yang menyebabkan jumlah penduduk lansia terbesar di dunia (Jurnal Kementrian Kesehatan Republik Indonesia, 2013).

Sukoco (1991) menyatakan bahwa pelayanan sosial dalam arti luas adalah setiap pelayanan yang dimaksudkan untuk meningkatkan kesejahteraan sosial manusia, sedangkan dalam arti sempit ialah pelayanan yang diberikan kepada sebagian masyarakat yang kurang atau tidak beruntung (Tamba et al 2014: 163). Program untuk menjaga kualitas hidup lansia yaitu melalui Panti Sosial Tresna Wredha (PSTW), Dekon, Pusaka dan organisasi sosial. Pelayanan kesejahteraan bagi lanjut usia sejak tahun 2010 telah mengalami peningkatan, sebanyak 56.041 lanjut usia terlayani, dan 2.746 lembaga/instansi telah melayani lansia (Dir. Pelayanan Sosial Lanjut Usia, 2010, dalam Yanrehsos, 2010). Keseluruhan lansia yang telah mendapat pelayanan sosial dari berbagai program, baik melalui PSTW, luar panti, dekonsentrasi dan uji coba PLJSU sebanyak 143.131 jiwa (Dir. Pelayanan Sosial Lanjut Usia, 2010; dalam Yanrehsos, 2010). Pada saat dikomparasikan dengan jumlah lansia terlantar, jumlah lansia penerima pelayanan sosial masih sangat kecil (Sriyanto Eko, 2012: 75). Menurut Muthia, Krisnani, dan Meilany (2016: 345), menyatakan bahwa penanganan permasalahan lanjut usia yang berkembang selama ini dikenal dengan melalui dua cara, yaitu pelayanan dalam panti dan luar panti.

Merujuk pada Peraturan Menteri Sosial No. 19 tahun 2012 tentang Pedoman Pelayanan Sosial Lanjut Usia, pada pasal 7 tercantum bahwa pelayanan dalam panti dilakukan dengan tujuan untuk meningkatkan kualitas hidup, kesejahteraan, dan terpenuhinya kebutuhan dasar lanjut usia. Adapun jenis pelayanan yang diberikan dalam panti, meliputi: 1) pemberian tempat tinggal yang layak; 2) jaminan hidup berupa makan, pakaian, pemeliharaan kesehatan; 3) pengisian waktu luang termasuk rekreasi; 4) bmbingan mental, sosial, keterampilan, agama; dan 5) pengurusan pemakaman atau sebutan lainnya (Sulastri dan Humaedi, 2017: 160). Penanganan permasalahan lanjut usia di dalam panti terdapat pekerja sosial, bekerja sama dengan dokter, psikolog, serta pemuka agama. Sebuah lembaga tidak akan berjalan dengan baik apabila komponen-komponen yang ada didalamnya tidak melaksanakan tugas mereka masing-masing secara benar.

Undang-Undang Permensos Nomor 17 Tahun 2012 tentang Akreditasi Lembaga Kesejahteraan Sosial pasal 6 ayat 1 menyatakan akreditasi dilakukan setelah lembaga di bidang kesejahteraan sosial memenuhi standar pelayanan minimal pelaksanaan pelayanan kesejahteraan sosial, yang meliputi program, sumber daya manusia, managemen organisasi, 
sarana dan prasarana, proses pelayanan dan hasil pelayanan. Maka dari itu penting adanya profesionalitas dari para dokter, psikolog, pemuka agama, dan yang paling utama yaitu dari pekerja sosial dalam suatu lembaga tersebut.

Menurut UU Nomor 11 tahun 2009 tentang Kesejahteraan Sosial, seseorang yang bekerja, baik di lembaga pemerintah maupun swasta yang memiliki kompetensi dan profesi pekerjaan sosial, dan kepedulian dalam pekerjaan sosial yang diperoleh melalui pendidikan, pelatihan, dan/atau pengalaman praktek pekerjaan sosial untuk melaksanakan tugas-tugas pelayanan dan penanganan masalah sosial. Salah satu bidang garapan pekerja sosial yaitu permasalahan tentang lanjut usia.

Pada abad ke-21 ada tantangan khusus bagi permasalahan tentang lansia, yaitu pada bidang kesehatan dari terus meningkatnya jumlah lansia yaitu timbulnya masalah degeneratif dan Penyakit Tidak Menular (PTM) seperti diabetes, hipertensi, dan gangguan-gangguan kesehatan jiwa yaitu depresi, demensia, gangguan cemas, sulit tidur. Penyakit-penyakit tersebut, akan menimbulkan permasalahan jika tidak diatasi atau tidak dilakukan pencegahan, karena ini akan menjadi penyakit yang bersifat kronis dan multi patologis. Oleh karena itu perhatian semua negara terhadap masalah kelanjut usiaan ini harus terus diantisipasi, karena akan ada ketergantungan biaya yang sangat besar, biasanya Lansia itu penyakitnya lebih dari 10 seperti gangguan penglihatan, gangguan pendengeran, nafsu makan, dan sulit tidur. Apabila permasalahan Lansia ini tidak ada aksi atau kesadaran semua stakeholder, maka bukan hanya akan terjadi permasalahan dibidang kesehatan tapi juga termasuk layanan sosial dan sebagainya, maka akan menimbulkan ancaman triple burden, yaitu jumlah

Bisman dalam Suharto (2011: 92), menyatakan dalam konteks ilmu dan praktik pekerja sosial, populasi atau klien yang paling banyak dan paling rentan adalah kelompok anak-anak dan usia tua (children and elderly). Meskipun pada kenyataannya dibandingkan dengan isu yang lain seperti anak, perempuan, dan lain-lain masih sedikit sekali para praktisi dan profesional pekerja sosial yang fokus kepada lansia.

Pekerja sosial dalam melaksanakan pekerjaan sosial dituntut memiliki keterampilanketerampilan. Keterampilan pekerjaan sosial dapat diartikan sebagai kemampuan pekerja sosial untuk menerapkan kemampuannya secara efektif dalam praktik pelayaan sosial kepada klien. Penguasaan keterampilan bagi pekerja sosial bersifat meningkat, artinya dari tingkat yang rendah sampai pada tingkat yang tinggi. Pekerja sosial diharapkan menguasai lima keterampilan dasar pekerjaan sosial, yaitu: 1). Keterampilan memberikan pertolongan dasar (Basic helping skills), 2). Keterampilan melakukan perjanjian (Engagement skills), 3). Keterampilan melakukan observasi (Observation skills), 4). Keterampilan melakukan komunikasi (Communication skills), 5). Keterampilan berempati (Emphaty skills) (Hermawati, 2001: 22).

Golongan lansia sering dipersepsikan sebagai orang yang tidak bisa menghasilkan apa-apa lagi. Kerjanya hanya merepotkan lingkungan terutama keluarga dan sehari-hari hanya 'duduk manis' serta istirahat di rumah. Bukannya membantu, kondisi scperti itu justru menimbulkan pengaruh buruk bagi mereka. Lansia sebenarnya masih bisa produktif. Golongan ini justru mempunyai kelebihan lain, salah satu diantaranya yaitu memiliki keunggulan pengalaman. "Banyak juga golongan tua yang masih kuat." Pernyataan ini disampaikan oleh Titus usai konferensi pers tentang Hari Lanjut Usia Nasional pada 29 Mei 2008. Pemerintah perlu mengusahakan agar para lansia bisa hidup produktif dengan melakukan pemberdayaan (Suhartini, 2009: 132).

\section{KAJIAN TEORI}


Federasi Internasional Pekerja Sosial (International Federation Social Work) dalam Pujileksono (2016: 161), menetapkan tiga bidang aksi utama pekerja sosial yang dapat dirincikan sebagai berikut: 1). Mempromosikan perubahan sosial, berdasarkan temuannya mengenai kebutuhan dan penyebab dihindari masalah yang dihadapi oleh individu dan kelompok pencari atau yang membutuhkan bantuan; 2). Pemecahan masalah dalam hubungan manusia, baik interpersonal, intrafamilial, dalam masyarakat luas atau vis-a-vis pemerintah dan agen-agen mereka; 3). Memberdayakan masyarakat untuk meningkatkan sendiri kesejahteraan mereka, sebagai lawan untuk menciptakan ketergantungan yang berkelanjutan dan dengan demikian mempertahankan kerentanan yang melekat.

Ocktilia (2017: 14), menyatakan proses pertolongan atau pelayanan dalam praktek pekerjaan sosial meliputi: 1). EIC (Engagement, Intake, Contract), merupakan suatu tahap awal dalam praktek pertolongan, yaitu kontak awal antara pekerja sosial dengan klien yang berakhir dengan kesepakatan untuk terlibat dalam keseluruhan proses, 2). Assessment (pengungkapan dan pemahaman masalah), merupakan suatu tahapan untuk mempelajari masalah-masalah yang dihadapi klien. Tahap ini berisi pernyataan masalah, assessmen kepribadian, analisis situasional, perumusan secara integratif dan evaluasi, 3). Planning (perencanaan), merupakan suatu pemilihan strategi, teknik dan metode yang didasarkan pada proses assessmen masalah, 4). Intervention (intervensi), merupakan suatu kegiatan yang bertujuan untuk menghasilkan perubahan berencana dalam diri klien dan situasinya, 5). Evaluation (evaluasi), merupakan suatu penilaian terhadap pencapaian tujuan yang telah ditetapkan dalam planning, serta melihat kembali kemajuan-kemajuan yang telah dicapai sehubungan dengan tujuan, 6). Termination (terminasi), tahap ini dilakukan bila tujuan-tujuan yang telah disepakati dalam kontrak telah dicapai dan mungkin sudah tidak dicapai kemajuan-kemajuan yang berarti dalam pemecahan masalah.

Thoburn June (2017: 97), berpendapat bahwa "The unequal level of funding between the different entry routes into social work is distorting choice between fast-track specialist and mainstream social work education. It is hypothesised that differences between the curricula and learning experiences of the two routes may have an impact on the social work service available to vulnerable people across age and needs groups" Yang berarti "Tingkat pendanaan yang tidak sama antara rute masuk yang berbeda ke dalam pekerjaan sosial adalah pilihan yang menyimpang antara spesialis jalur cepat dan pendidikan kerja sosial utama. Ini adalah hipotesis bahwa perbedaan antara kurikulum dan pengalaman belajar dari dua rute dapat berdampak pada layanan pekerjaan sosial yang tersedia untuk orang yang rentan di seluruh kelompok usia dan kebutuhan kelompok tersebut." dari pendapat tersebut dapat dilihat bahwa perbedaan latar belakang pendidikan yang berbeda dari pekerja sosial profesional dengan yang bukan memiliki kualifikasi pelayanan klien yang berbeda.

Soetarso (dalam Alamsyah, 2015: 14) mengemukakan bahwa pekerja sosial memiliki tugas-tugas yang meliputi: 1) Pekerja sosial menentukan dan mengadakan hubungan dengan orang yang membutuhkan bantuan guna menyelesaikan tugas kehidupannya, 2) Pekerja sosial dapat memberikan pengertian, dukungan, dan dorongan kepada orang yang mengalami krisis masalah, 3) Pekerja sosial dapat memberikan kesempatan kepada orang untuk mengutarakan kesulitan-kesulitannya, 4) Pekerja sosial dapat membantu orang untuk memilih berbagai pilihan cara mengatasi masalah, 5) Pekerja sosial dapat mengonfrontasikan orang dengan realitas situasi sosial yang mereka hadapi, 6) Pekerja sosial dapat mengajarkan keterampilan kepada orang untuk mewujudkan gagasan-gagasan dan aspirasinya.

Penelitian ini dilakukan di Wisma Lansia Husnul Khatimah Semarang. Wisma Lansia Husnul Khatimah merupakan salah satu yayasan panti sosial yang merawat dan memenuhi 
kebutuhan lanjut usia dengan visi terwujudnya lembaga pelayanan yang membantu mengantarkan lansia menuju husnul khatimah. Sedangkan misi dari Wisma Lansia Husnul Khatimah Semarang yaitu: 1). Menyelenggarakan pelayanan bagi lanjut usia dalam pemenuhan kebutuhan fisik, mental, sosial, dan spiritual; 2). Menyelenggarakan pelayanan bagi lanjut usia dalam pemenuhan kebutuhan kearah pribadi sehat sesuai syariat islam agar dapat hidup bahagia. Serta bertujuan memberdayakan lansia menjadi sehat, produktif, mandiri, dan memiliki nilai religius.

Wisma Lansia Husnul Khatimah Semarang juga memiliki tujuan untuk memberikan pelayanan sosial yang optimal kepada penerima manfaat yaitu lansia melalui pemberian pelayanan didalam wisma lansia untuk memberdayakan lansia menjadi produktif, mandiri, sehat, serta memiliki nilai-nilai religius. Dalam pemberian pelayanan sosial wisma lansia memiliki pekerja sosial yang bertugas melaksanakan program kegiatan berupa, pemenuhan kebutuhan lansia, penyelesaian permasalahan lasia, memberi dorongan dan motivasi, memfasilitasi lansia untuk menjaga kesehatan jasmani \& rohani mereka, mengonfrontasi lansia sesuai dengan situasi sosial yang mereka jalani, serta memberikan keterampilan pada lansia. Kegiatan-kegiatan tersebut dilaksanakan dengan tujuan agar lansia berdaya dalam melaksanakan kegiatan mereka setiap harinya.

\section{METODE PENELITIAN}

Penelitian ini dilakukan di Wisma Lansia Husnul Khatimah Semarang dengan pendekatan penelitian deskriptif kualitatif. Subyek penelitian ini berjumlah 4 orang yang terdiri 3 orang pekerja sosial, dan 1 orang penerima manfaat yaitu lansia, serta 4 orang informan yang terdiri dari 3 orang perawat dan 1 orang pengelola wisma. Sumber data yang digunakan yaitu sumber data primer dan data sekunder. Data primer adalah sumber data yang langsung memberikan data kepada pengumpul data, dalam penelitian ini data primer diperoleh melalui wawancara dengan subyek dan informan penelitian. Data sekunder adalah sumber yang tidak langsung memberikan data kepada pengumpul data, dalam penelitian ini data sekunder diperoleh dari observasi dan dokumentasi, catatan lapangan, laporan wawancara, dan laporan observasi lapangan. Teknik keabsahan data menggunakan triangulasi sumber dan metode. Teknik analisis data menggunakan pengumpulan data, reduksi data, display data, penarikan kesimpulan dan verifikasi.

\section{HASIL DAN PEMBAHASAN}

Wisma Lansia Husnul Khatimah Semarang didirikan atas dasar kebutuhan yang ada dimasyarakat sekitar berkaitan dengan masalah lansia. Banyaknya masyarakat yang memerlukan tempat untuk menitipkan anggota keluarganya yang sudah lanjut usia merupakan alasan wisma ini didirikan. Pembangunan wisma lansia ini diawali dengan adanya penerimaan tanah wakaf dari keluarga bapak H. Sutaman seluas $1.016 \mathrm{~m}$ x $2.913 \mathrm{~m}$ kepada pimpinan Daerah Muhammadiyah Kota Semarang yang berlokasi di RT 01/ RW 04 Dukuh Muntal, Kelurahan Mangunsari, Kecamatan Gunungpati, Semarang. Dengan visi lembaga yaitu "Terwujudnya lembaga pelayanan yang membantu mengantarkan lansia menuju husnul khatimah", maka Wisma Lansia Husnul Khatimah Semarang berharap dapat membimbing, membina, serta mengarahkan para lansia menuju akhir hayat yang husnul khatimah.

Menurut Muthia et al (2016: 345) menyatakan bahwa penanganan permasalahan lanjut usia yang berkembang selama ini dikenal dengan melalui dua cara, yaitu pelayanan dalam panti dan luar panti. Penanganan permasalahan lanjut usia di dalam panti terdapat pekerja sosial, bekerja sama dengan dokter, psikolog, serta pemuka agama. Sebuah lembaga 
tidak akan berjalan dengan baik apabila komponen-komponen yang ada didalamnya tidak melaksanakan tugas mereka masing-masing secara benar. Berdasarkan hal tersebut maka sudah seharusnya pekerjaan sosial yang ada di Wisna Lansia Husnul Khatimah Semarang dilaksanakan dengan benar sesuai amanah atau tugas dari yayasan tersebut. Berikut merupakan tugas-tugas yang harus dilaksanakan oleh pekerja sosial untuk dapat memberdayakan lanjut usia.

\section{Menjalin Hubungan Baik \& Membantu Memenuhi Kebutuhan}

Pekerja sosial dalam melaksanakan tugasnya terhadap lansia harus melakukan pendekatan terlebih dahulu. Selain melakukan pendekatan pekerja sosial juga dituntut memiliki kecakapan dalam hal sosialisasi dan interaksi kepada lansia. Cara pendekatan yang tepat serta keterampilan sosialisasi dan interaksi yang mumpuni akan menciptakan hubungan baik antara pekerja sosial dengan lansia, serta dapat mempermudah pekerja sosial dalam membantu lansia memenuhi kebutuhannya dan mengatasi permasalahan yang mereka hadapi.

Pekerja sosial melakukan pendekatan supaya lansia mau menerima dan menerapkan saran atau solusi permasalahan yang diberikan kepadanya. Pendekatan yang diterapkan biasanya menyesuaikan dengan keadaan dan kondisi yang tengah dihadapi lansia. Hal ini sesuai dengan yang dikemukakan oleh Wibawa dalam Pujileksono (2016: 157), bahwa seorang pekerja profesional yang terlatih mampu menganilisis situasi-situasi komplek dan memfasilitasi perubahan-perubahan secara individual, organisasional, sosial, dan kultural. Selain dengan pendekatan, bagaimana sosialisasi dan interaksi antara pekerja sosial dengan lansia juga dapat mempengaruhi sikap keterbukaan lansia. Pincus dan Minahan (dalam Sumarnugroho, 1984: 96) menyatakan bahwa pekerjaan sosial adalah suatu bidang yang melibatkan interaksi-interaksi diantara orang dengan lingkungan sosial mereka yang mempergunakan kemampuan orang untuk menyelesaikan tugas-tugas kehidupan mereka, mengatasi penderitaan, mewujudkan aspirasi-aspirasi serta nilai-nilai mereka.

\section{Memberikan Motivasi \& Dorongan}

Pemberian motivasi serta dorongan kepada lansia bertujuan agar lansia dapat menjalani kehidupannya dengan semangat dan penuh dengan harapan baru setiap harinya. Walaupun motivasi terbesar memang berasal dari diri sendiri, namun para lansia juga membutuhkan orang lain untuk membantunya menumbuhkan motivasi tersebut. Hal ini disebabkan karena emosi lansia yang tidak stabil maka akan mempengaruhi perasaan dan semangat mereka, dengan adanya permasalahan tersebut pekerja sosial dituntut cepat tanggap terhadap kondisi lansia dan dapat membantu memberikan dorongan disaat-saat sulit mereka.

Erikson dalam Triwanti (2015: 412) mengungkapkan ada delapan tahap perkembangan manusia bahwa jika di dalam tahap perkembangannya lansia memiliki integritas yang rendah maka lansia akan sulit menerima akhir dari hidupnya dan mengalami kecemasan dalam menjalani hidup. Dengan adanya pemberian motivasi dan dorongan serta perhatian dan kasing sayang dari pekerja sosial serta karyawan lainnya, maka lansia dapat mengurasi rasa cemas dalam dirinya terhadap apa yang mereka hadapi, serta dapat menatap hari yang baru dengan penuh semangat dan harapan.

\section{Membantu Menyelesaikan Permasalahan Lansia}

Secara individual, lansia memiliki permasalahan yang berbeda-beda. Permasalahan dapat berasal dari dalam diri lansia maupun lingkungan disekitarnya, seperti permasalahan penyakit pikun, dan berkurangnya interaksi sosial lansia dengan lingkungan sekitarnya. Untuk membantu lansia menyelesaikan permasalahannya pekerja sosial memiliki strategi untuk menganalisis dan mengetahui apa saja permasalahan yang dihadapi lansia, hal ini dilakukan agar pekerja sosial dapat membantu lansia dalam mencari solusi terbaik untuk peyelesaian 
permasalahan tersebut. Pekerja sosial juga mengarahkan lansia dalam mengembangkan kemampuan sosialisasi, hal ini bertujuan agar lansia dapat berinteraksi dengan lingkungan sekitar, dengan begitu mereka tidak akan merasa kesepian dalam keseharian mereka.

Dalam membantu menyelesaikan permasalahan yang lansia hadapi, pekerja sosial harus menyesuaikan dengan kondisi serta situasi lansia. Hal ini dikarenakan dalam menghadapi kondisi masalah yang sama pun, setiap lansia menghadapinya secara berbeda, tergantung pada cara pandang dan cara menyikapinya, atau kepribadiannya. Kepribadian adalah semua corak perilaku dan kebiasaan individu yang terhimpun dalam dirinya dan digunakan untuk bereaksi serta menyesuaikan diri terhadap segala rangsangan baik dari luar maupun dari dalam. Corak perilaku dan kebiasaan ini merupakan kesatuan fungsional yang khas pada seseorang. Kepribadian manusia yang sudah terbentuk sebelum masa lansia dan bersifat dinamis dapat berkontribusi dalam menghadapi permasalahan ketika lansia (Sulastri, 2017: 159). Dengan mengetahui hal-hal tersebut pekerja sosial dapat mengarahkan lansia pada pilihan solusi terbaik dalam menyelesaikan permasalahan mereka.

\section{Memfasilitasi Lansia untuk Menjaga Kesehatan Jasmani \& Rohani}

Diusia yang sudah tidak muda lagi lansia mengalami kemunduran fungsi fisik maupun perubahan emosional, dengan kondisi tersebut lansia memerlukan penanganan yang intens. Lansia membutuhkan pekerja sosial sebagai fasilitator untuk memenuhi kebutuhan mereka untuk menjaga kesehatan jasmani dan rohaninya. Untuk kesehatan jasmani sendiri Wisma Lansia Husnul Khatimah Semarang mempunyai program seperti cek tensi rutin setiap hari, lalu cek gula darah dan cek kolestrol, senam lansia atau sekedar menggerakkan anggota tubuh secara sederhana bagi lansia yang sudah mengalami bedrest. Hal ini dilakukan agar lansia dapat berolahraga walaupun dengan gerakan-gerakan sederhana dengan harapan sendi-sendri mereka tidak bertambah kaku atau sakit.

Kondisi lansia ini juga sama seperti yang dikemukakan oleh Jalaluddin (1999), pada mada lanjut usia seseorang cenderung mengalami kemunduran fungsi, baik secara fisik, psikologis maupun sosial. Penurunan secara fisik pada umumnya dipengaruhi menurunnya pembuluh darah, khususnya pembuluh darah kapiler. Akibatnya jumlah darah yang mengalir ke organ tubuh menjadi menurun, sehingga mengakibatkan pengerutan organ tubuh. Dampak pada otak manusia adalah kemunduran fungsi daya ingat. Secara psikis, terjadi pula perubahan khas berupa gejala kecemasan, cenderung menjadi kurang bersih, dan gejala paranoid lainnya seperti keras kepala, egoistis, mudah tersinggung, gelisah dan sebagainya (Wulandari, 2014: 427).

Selain memperhatikan kesehatan jasmani, Wisma Lansia Husnul Khatimah Semarang juga memiliki berbagai kegiatan untuk menjaga kesehatan rohani para lansia. Kegiatan ini berupa kegiatan mengaji, menghafalkan doa-doa dan bacaan wirid, serta pengajian bulanan yang berisi ceramah dari seorang pemuka agama. Hal ini dilakukan agar lansia dapat mengontrol tingkat emosionalnya dan tetap bisa mempelajari ilmu agama serta menyiapkan bekal mereka di akhirat nanti serta dapat meninggal dengan keadaan husnul khatimah seperti visi dari lembaga tersebut.

Semua kegiatan yang ada baik kegiatan untuk menjaga kesehatan jasmani maupun kegiatan untuk menjaga kesehatan rohani dilakukan agar lansia tetap bisa menjalankan aktivitas rutinnya. Semua program yang ada di wisma dilaksanakan dengan tetap menyesuaikan kondisi lansia, agar lansia dapat mengikuti setiap kegiatan dengan kondusif dan dapat berpartisipasi aktif didalamnya serta dapat meningkatkan kemandirian lansia.

\section{Pekerja Sosial Mengonfrontasikan Lansia dengan Realitas Situasi Sosial}


Salah satu tugas pekerja sosial dalam melaksanakan pekerjaan sosial adalah mengonfrontasikan lansia dengan realitas siatusi sosial mereka. Dalam melaksanakan tugasnya pekerja sosial harus dapat menyadarkan atau mengonfrontasi lansia agar mereka tahu realitas situasi sosial yang mereka hadapi saat ini. Proses ini biasanya dilaksanakan melalui sesi bimbingan yang dilakukan pekerja sosial, baik itu saat bimbingan sosial, bimbingan mental, maupun bimbingan agama.

Lanjut usia merupakan seorang individu yang sudah melewati masa golden age dan sudah memasuki usia 60 tahun. Pada usia ini, banyak kemunduran yang dihadapi oleh para lanjut usia baik itu dari segi fisik, psikis, maupun sosial. Kemunduran yang dialami oleh lansia merupakan proses alami yang disebut dengan proses degeneratif. Pada tahap ini lansia mengalami kesulitan untuk melewati masa tuanya, karena sebagian orang beranggapan bahwa lansia tidak dapat berbuat apa-apa atau tidak berguna. Semakin bertambahnya usia yang terjadi melalui proses alamiah pada lanjut usia, maka semakin banyak ketergantungan yang dialami oleh lanjut usia. Hal tersebut disebabkan menurunnya kondisi fisik, psikis maupun sosial sehingga penurunan yang dialami oleh para lanjut usia akan memperlambat proses interaksi yang terjadi di dalam lingkungan (Triwanti, 2015: 411).

Adanya kemunduran fungsi baik itu fisik, psikis, maupun emosional lansia menyebabkan banyak hal yang mereka halusinasikan dan berbeda dari apa yang mereka hadapi saat ini, dengan itu perlu adanya arahan dari pekerja sosial tentang situasi apa yang sebenarnya lansia hadapi sekarang.

\section{Pekerja Sosial Mengajarkan Keterampilan Kepada Lansia}

Pemberian keterampilan pada lansia menyesuaikan pada situasi dan kondisi lansia agar dapat dilaksanakan dengan maksimal. Di Wisma Lansia Husnul Khatimah Semarang sendiri berfokus pada pemberian soft skills karena hard skills dirasa tidak terlalu dibutuhkan oleh lansia. Soft skills yang diberikan oleh pekerja sosial berupa arahan bagaimana agar lansia dapat menentukan suatu keputusan serta dapat berinisiatif untuk melakukan suatu hal atau kegiatan yang mereka inginkan.

Merujuk pada Peraturan Menteri Sosial No. 19 tahun 2012 tentang Pedoman Pelayanan Sosial Lanjut Usia, pada pasal 7 tercantum bahwa pelayanan dalam panti dilakukan dengan tujuan untuk meningkatkan kualitas hidup, kesejahteraan, dan terpenuhinya kebutuhan dasar lanjut usia. Adapun jenis pelayanan yang diberikan dalam panti, meliputi: 1) pemberian tempat tinggal yang layak; 2) jaminan hidup berupa makan, pakaian, pemeliharaan kesehatan; 3) pengisian waktu luang termasuk rekreasi; 4) bmbingan mental, sosial, keterampilan, agama; dan 5) pengurusan pemakaman atau sebutan lainnya (Sulastri dan Humaedi, 2017: 160). Maka dari itu pemberian keterampilan diberikan tujuan untuk meningkatkan kualitas hidup, kesejahteraan, dan terpenuhinya kebutuhan dasar lanjut usia.

\section{Faktor Pendukung \& Faktor Penghambat Pelaksanaan Tugas Pekerja Sosial dalam Memberdayakan Lansia}

Berdasarkan data penelitian yang telah dilakukan dapat diketahui bahwa pelaksanaan tugas pekerja sosial dalam memberdayakan lansia di Wisma Lansia Husnul Khatimah Semarang memiliki faktor pendukung dan juga faktor penghambat, baik yang berasal dari faktor internal maupun dari faktor eksternal.

1. Faktor Pendukung Pelaksanaan Tugas Pekerja Sosial dalam memberdayakan Lansia

Faktor pendukung pekerja sosial dalam melaksanakan tugasnya dalam memberdayakan lansia yaitu motivasi dalam diri pekerja sosial sendiri, rasa kemanusiaan dan ingin menolong sesama adalah yang menjadi dasar mengapa pekerja sosial tetap melaksanakan tugasnya dengan sabar dan ikhlas. Selain itu terdapat juga faktor lain yang menunjang pelaksanaan 
tuga pekerja sosial, yaitu bagaimana kondisi lingkungan kerjanya serta rekan kerja pekerja sosial tersebut. Apabila kondisi lingkungan kerja ini kondusif dan rekan kerjanya dapat bekerjasama dengan baik maka pekerja sosial akan dapat optimal dalam menjalankan tugasnya.

Karena telah diamanatkan tugas sebagai pekerja sosial, mereka memiliki tanggung jawab untuk mendampingi lansia selama di wisma seperti teori kesejahteraan, yaitu menurut Fahruddin (2012: 93), pekerja sosial pada umumnya membantu, mewakili, dan bertanggung jawab baik kepasa lansia secara individual maupun kepada masyarakat secara keseluruhan.

Setiap komponen yang ada di wisma harus dapat berkontribusi dan saling membantu agar dapat menunjang terlaksananya tugas pekerja sosial dalam memberdayakan lansia, agar lansia juga dapat tetap berkembang dan berlatih mandiri dalam kelangsungan hidupnya.

2. Faktor Penghambat Pelaksanaan Tugas Pekerja Sosial dalam Memberdayakan Lansia

Pekerja sosial dalam melaksanakan tugasnya untuk memberdayakan lansia sering mendapatkan hambatan. Dalam pelaksanaan tugasnya pekerja sosial bekerjasama dengan pegawai lain dalam pendampingan lansia di wisma. Terkadang faktor internal yang menjadi penghambat tugas pekerja sosial adalah rasa lelah yang menghinggapi pekerja sosial, karena harus terus fokus dalam membantu dan mendampingi lansia maka tidak dapat dipungkiri bahwa rasa lelah pasti pernah dirasakan oleh para pekerja sosial. Namun karena tanggung jawabnya kepada lansia para pekerja sosial tetap semangat dan menyingkirkan rasa lelah tersebut.

Faktor penghambat lainnya berasal dari para lansia yang terkadang memiliki emosi yang tidak stabil sehingga menuntut para pekerja sosial bersabar untuk menghadapinya selama kegiatan berlangsung, selain itu juga terkadang lansia juga sulit untuk diminta berpartisipasi aktif dalam kegiatan wisma. Banyak perubahan yang dikaitkan dengan proses menua merupakan akibat dari kehilangan yang bersifat bertahap (gradual loss). Lansia mengalami perubahan-perubahan fisik diantaranya perubahan sel, sistem persarafan, sistem pendengaran, sistem penglihatan, sistem kardiovaskuler, sistem pengaturan suhu tubuh, sistem respirasi, sistem gastrointestinal, sistem genitourinari, sistem endokrin, sistem muskuloskeletal, disertai juga dengan perubahan-perubahan mental menyangkut perubahan ingatan atau memori (Setiati et al, 2006).

Namun faktor-faktor penghambat tersebut dapat diatasi dengan adanya rasa kemanusiaan, ketulusan dan perhatian yang lebih dari pekerja sosial dalam melaksanakan tugasnya membantu dan mendampingi lansia. Dengan kesabaran dan keikhlasan yang pekerja sosial tunjukkan lama-kelamaan lansia merasa luluh dan mau mengikuti arahan pekerja sosial untuk kebaikan diri mereka sendiri.

\section{SIMPULAN DAN SARAN}

Berdasarkan hasil penelitian yang telah diuraikan dapat disimpulkan bahwa pelaksanaan tugas pekerja sosial dalam memberdayakan lansia di Wisma Lansia Husnul Khatimah Semarang, meliputi :

1. Menjalin Hubungan Baik \& Membantu Memenuhi Kebutuhan

Tugas pekerja sosial dalam memberdayakan lansia di Wisma Husnul Khatimah Semarang yang pertama yaitu menjalin hubungan baik dan membantu memenuhi kebutuhan lansia, dengan interaksi yang baik antara pekerja sosial dan lansia maka lansia akan lebih terbuka terhadap pekerja sosial.

2. Memberikan Morivasi \& Dorongan 
Tugas pekerja sosial dalam memberdayakan lansia di Wisma Husnul Khatimah Semarang yang kedua yaitu memberikan motivasi serta dorongan kepada lansia, motivasi dan dorongan diberikan pada lansia agar mereka merasa semangat kembali dalam menjalani kehidupan mereka.

3. Membantu Menyelesaikan Permasalahan Lansia

Tugas pekerja sosial dalam memberdayakan lansia di Wisma Husnul Khatimah Semarang yang ketiga membantu lansia menyelesaikan permasalahan mereka, dengan memperhatikan situasi dan kondisi lansia pekerja sosial mengarahkan lansia dalam memilih solusi terbaik bagi permasalahan mereka. Dan

4. Memfasilitasi Lansia untuk Menjaga Kesehatan Jasmani \& Rohani

Tugas pekerja sosial dalam memberdayakan lansia di Wisma Husnul Khatimah Semarang yang keempat yaitu pekerja sosial juga bertugas sebagai fasilitator yang memfasilitasi lansia untuk menjaga kesehatan jasmani serta rohani, hal ini untuk membuat lansia dapat berdaya dan mandiri didalam melaksanakan keberfungsian sosial mereka, serta menyiapkan bekal untuk akhirat mereka kelak.

5. Pekerja Sosial Mengonfrontasikan Lansia dengan Realitas Situasi Sosial

Tugas pekerja sosial dalam memberdayakan lansia di Wisma Husnul Khatimah Semarang yang kelima pekerja sosial harus menyadarkan lansia pada realita situasi yang mereka hadapi biasanya melalui sesi bimbingan, baik itu bimbingan sosial, mental, maupun agama.

6. Pekerja Sosial Mengajarkan Keterampilan Kepada Lansia

Tugas pekerja sosial dalam memberdayakan lansia di Wisma Husnul Khatimah Semarang yang keenam memberikan keterampilam yaitu soft skills berupa arahan agar lansia dapat membuat suatu keputusan serta dapat mengembangkan sikap inisiatif.

7. Faktor pendukung dan penghambat pelaksanaan tugas pekerja sosial dalam memberdayakan lansia di Wisma Lansia Husnul Khatimah Semarang

Faktor pendukung dan penghambat pelaksanaan tugas pekerja sosial dalam memberdayakan lansia di Wisma Lansia Husnul Khatimah Semarang terdiri dari faktor internal dan faktor eksternal. Adapun faktor pendukung dalam pelaksanaan tugas pekerja sosial dalam memberdayakan lansia adalah motivasi dari dalam diri pekerja sosial itu sendiri,dukungan dan kerjasama dari semua rekan kerja, serta faktor lingkungan kerja yang kondusif dan sarana prasarana yang memadai. Sedangkan, faktor yang menjadi penghambat pelaksanaan tugas pekerja sosial dalam memberdayakan lansia yaitu rasa lelah yang terkadang dialami oleh pekerja sosial namun hal itu dapat diatasi dengan adanya kesadaran dari para pekerja sosial atas tugas dan tanggung jawab yang telah diamanatkan kepadanya, selain itu faktor penghambat lainnya yaitu adanya sikap lansia yang terkadang tidak stabil serta penyakit yang diderita oleh lansia terkadang menyebabkan lansia tidak dapat mengikuti program kegiatan secara optimal.

Berdasarkan hasil penelitian dan simpulan yang telah diuraikan, maka penulis dapat menyampaikan beberapa saran kepada pihak-pihak yang terkait. Adapun penulis dapat merekomendasikan beberapa saran sebagai berikut :

1. Bagi pekerja sosial dan pegawai lainnya di Wisma Lansia Husnul Khatimah Semarang diharapkan dapat menjalin hubungan baik dengan rekan kerjanya serta berbagi informasi tentang pekerjaan mereka, agar memudahkan dalam melaksanakan tugas dan tanggung jawab yang diharapkan dapat menunjang pelaksanaan tugas pekerja sosial dalam memberdayakan lansia.

2. Bagi lembaga, diharapkan dapat melakukan perekrutan pekerja sosial yang memenuhi kompetensi-kompetensi seorang pekerja sosial professional, seperti memiliki kepribadian 
yang baik, memiliki rasa kemanusiaan, serta dapat memberikan pelayanan yang tepat terhadap permasalahan-permasalahan yang dihadapi lansia.

3. Bagi keluarga lansia, pihak keluarga diharapkan agar dapat memantau perkembangan atau kondisi lansia selama berada di wisma, serta sering melakukan kunjungan kepada lansia, hal ini diperlukan agar pekerja sosial dan keluarga dapat menjalin komunikasi yang baik dan bekerja sama dalam merawat dan memberdayakan lansia selama berada di Wisma Lansia Husnul Khatimah Semarang.

\section{DAFTAR PUSTAKA}

Alamsyah, Cepi Yusrun. (2015). Praktik Pekerjaan Sosial Generalis Suatu Tuntunan Intervensi. Yogyakarta: Pustaka Pelajar.

Fahrudin, Adi. 2012. Kesejahteraan Sosial Internasional. Bandung: Alfabeta.

Hermawati, 2001. Metode dan Teknik dalam Praktik Pekerjaan Sosial. Yogyakarta: ADICITA KARYA NUSA.

Kementerian Kesehatan Republik Indonesia. 2013. Populasi Lansia Diperkirakan Terus Meningkat Hingga Tahun 2020. Dipublikasikan Rabu, 09 Oktober 2013. www.depkes.go.id

Muthia, Githa, et.al. (2016). Peran Pekerja Sosial dalam Meningkatkan Keberfungsian Sosial Lansia di Panti Sosial Tresna Werdha Budhi Dharma Bekasi. Jurnal Riset \& PKM. Vol 3 (3): 347.

Ocktilia, 2017. Proses Pertolongan Praktek Pekerjaan Sosial. Jurnal Pekerjaan Sosial. 1-16.

Permensos No. 19 Tahun 2012 tentang Pedoman Pelayanan Lanjut Usia Pasal 7

Pujileksono, Sugeng. 2016. Perundang-Undangan Sosial dan Pekerja Sosial. Malang: Setara Press.

Setiati. (2006). Gangguan Keseimbangan, Jatuh, dan Fraktur. Buku Ajar Ilmu Penyakit Dalam. Jilid III. Edisi IV. Jakarta: Pusat Penerbitan Departemen Penyakit Dalam FKUI.

Sriyanto, Eko. 2012. Lanjut Usia: Antara Tuntutan Jaminan Sosial dan Pengembangan Pemberdayaan. KAWISTARA Vol 2 (1): 73-86..

Suhartini, (2009). Pemberdayaan Lansia dengan Aktivitas Olahraga Rekreasi Therapuetik. Jurnal Fakultas Ilmu Keolahragaan Universitas Negeri Yogyakarta Vol 5 (2): $131=140$.

Suharto, (2009). Pekerjaan Sosial di Dunia Industri. Bandung: Penerbit Alfabeta.

Jurnal Cendekiawan Ilmiah $\mathcal{P} \mathcal{L} S$ Vo 5 No 2 Desember 2020 
(2011). Pendidikan dan Praktik Pekerjaan Sosial di Indonesia dan Malaysia. Yogyakarta: Penerbit Samudra Biru.

(2007) Kebijakan Sosial Sebagai Kebijakan Publik: Memperkuat Pembangunan Kesejahteraan Sosial, Pekerjaan Sosial dan Negara Kesejahteraan di Indonesia, Bandung: Alfabeta.

Sulastri dan Humaedi, 2017. Pelayanan Lanjut Usia Terlantar Dalam Panti. Riset \& PKM Vol 4 (1): 1-140.

Sumarnonugroho, T. (1984). Sistem Intervensi Kesejahteraan Sosial. Yogyakarta: Penerbit PT. Hanindita

Tamba, et al. 2014. Pelayanan Sosial Bagi Remaja Putus Sekolah. Jurnal Pekerjaan Sosial Vol 2 (2): 160-165

Thoburn, June. 2017. In Defence of a University Social Worker Education. Journal of Children's Services Vol 2 (2-3): 97-106.

Triwanti, et al. 2015. Peran Panti Sosial Tresna Werdha Dalam Upaya Meningkatkan Kesejahteraan Lansia. Riset \& PKM Vol 2 (3): 301-444.

Undang-Undang Permensos No. 17 Tahun 2012 tentang Akreditasi Lembaga Kesejahteraan Sosial Pasal 6 Ayat 1.

Undang-Undang No 11 Tahun 2009 tentang Kesejahteraan Sosial Pasal 1 Ayat 2

Wulandari Dyah. (2014). Pelatihan Zadul Ma'ad (Bekal Ke Akherat) Untuk Mengurang Kecemasan Menghadapi Kematian Bagi Lansia. Jurnal Seminar

Nasional Hasil - Hasil Penelitian dan Pengabdian LPPM UMP 2014 